\title{
Treinta años después \\ (Jaime Gil de Biedma)
}

Antonio Jiménez Millán

A Pere Rovira

Mantener la distancia es un aprendizaje que cuesta muchos ańos y algunas decepciones.

Lo insinuaba él con su voz grave, hablando de Galdós, de Eliot, de Oscar Wilde, o del viejo poema provenzal que le sirvió para escribir su Albada.

Había que aprender también de los silencios y de las reticencias, sobre todo.

Nos dejó la leyenda

de aquel sótano oscuro en calle Muntaner y las conversaciones entre el alcohol y el humo, pero las copas de la madrugada no eran para él una forma de olvido, sino un refugio astuto para no soportar majaderías.

Mantener la distancia es un aprendizaje.

Lejos de la efusión sentimental

de los más jóvenes, no me queda nostalgia

de la promiscuidad.

Tampoco me seducen como antes las noches de aventura en sórdidos hoteles ni los amaneceres en la playa, 
los amores difíciles que ya son imposibles.

Aunque el deseo, a veces, despliega sus fantasmas.

Ahora todo está mucho más claro:

en la vida y en la literatura

hay que saber guardar distancias,

no creerse los fuegos de artificio.

(De Biología, historia, 2018) 